\title{
Perception of Vulnerable Ultra-Poor Women on Climate Change Impacts and Local Adaptation in a High Flood Prone Area of Bangladesh
}

\author{
Md. Shareful Hassan \\ Center for Environmental Change Studies and Management, \\ Dhaka, Bangladesh
}

Syed Mahmud-ul-Islam

Institute of Environmental Science, University of Rajshahi, Rajshahi, Bangladesh

Mohammad Mahbubur Rahman

Department of Sociology, Lancaster University, Bowland North, UK

Saeid Eslamian

Department of Water Engineering, Collage of Agriculture, Isfahan University of Technology, Isfahan 84156 83111, Iran

\begin{abstract}
The contextual and risk perception of climate change plays a critical role in an individual's decisionmaking process. It could also help people to respond appropriately to the consequences of global climate change and eventually take necessary adaptation actions. However, the perceptions of climate change are often gendered and vary among men and women. Therefore, this study explores different perceptions of climate change and its local adaptation options among ultra-poor vulnerable women, particularly in highly vulnerable flood-prone regions of Bangladesh. The research followed an empirical research methodology to collect primary and secondary information using qualitative and quantitative research tools. The study findings reveal that climate change perceptions at the individual level are relatively low (63\%). Still, they have been observing significant changes in various climatic variables over the past 30 years. Moreover, this study identified some major adaptation options such as plinth raising $(100 \%)$, livestock rearing (100\%), homestead gardening (82\%), seasonal migration (82\%), and using indigenous knowledge $(69 \%)$, and so on to tackle the adverse impacts of climate change-induced extreme events including flooding at the local level. For implementing these adaptation measures, the respondents spent a significant amount of financial resources from individual sources in the study area. Structural Equation Modeling (SEM) is used in addition to the statistical analyses to understand any connections between the climate change perceptions and other variables associated with the community under study. The SEM result shows that climate change will be a longterm problem, which offers a strong predictor in this model, considering standardized regression weight $\beta=0.56$. It means, despite inadequate knowledge on climate change of the respondent's, climate change is occurring and becoming the worst factor limiting cultural, economic, and environmental development in the study area.
\end{abstract}

KEYWORDS: Climate change, vulnerable women, perception, adaptation, Bangladesh, high flood 


\section{Introduction}

Climate change poses considerable uncertainty concerning both the intensity and the temporal or spatial pattern of its impacts on the individual's decision-making process (Woods et al., 2017). Research findings on how people act under high uncertainty conditions suggest that individuals consistently overlook the risk of a disaster affecting them, and these have profound implications (Grothmann and Patt, 2005). Contextual perceptions of risk are unconsciously chosen ideologies that facilitate an individual's way of life, as explained by cultural cognition theory (Lacroix and Gifford, 2018). Every individual has beliefs about how the world should be. Because some risks promote particular ideas more than others, individuals "selectively...attribute or deny the evidence of risk in patterns that match values that they exchange with each other" (Kahan et al., 2011). For instance, considering that egalitarians do not like unfair social disparities (Kahan, 2008; Kahan and Braman, 2003); and given that most people believe climate change risks to others around the world to be higher than the risks to themselves, it follows that egalitarians are more likely to be involved with climate change because it endangers their view of a socially fair and equitable society (Lacroix and Gifford, 2018).

Risk perception is a mental construct (Sjöberg, 2000). Human perception is exceptional since it makes it possible to distinguish between the nature of concrete, immediate threats, such as climate change, and the subjective perception of those threats (Rosa, 2003). For instance, even though anthropogenic global warming is one of the biggest global threats to human existence, risk assessments of global climate change vary considerably from one individual to another (Hine et al., 2013; van der Linden, 2017). Moreover, there is a substantial cross-cultural difference in the intensity of combined public concern and a general eagerness to address the problem. In the United Kingdom, Australia, and most of mainland Europe, climate change, for instance, has always been seen as a "substantial" problem. On the other hand, it has traditionally been gained lower attention in countries such as the United States, China, and Russia (van der Linden, 2017). Of that kind, prejudices can skew perceptions of risk, a key mechanism for motivating adaptive behavior. For example, studies of flood insurance purchases have shown that, even if the flood damage is severe, people prefer to disregard the possibility of flood risks when they have a low flood probability scenario (Woods et al., 2017).

The differential consequences of climate change on men and women emerge from diverse roles in society, how these roles are boosted or diminished by other aspects of injustice, perceived risks, and the nature of disaster response (Field et al., 2014). Vulnerability study results on climate change showed that the factors of men's and women's vulnerability and adaptation capacity were gender-sensitive and mediated by cultural, socio-economic, and political structures and processes (Carr and Thompson, 2014). Moreover, several socio-demographic variables, including gender, race, education, access to the property, and social networks, can be used to label the most vulnerable (Baptiste and Kinlocke, 2016). In general, women have often been perceived by their increasing dependence upon natural resources and increased poverty among 
the most vulnerable victims of climate change (Arora-Jonsson, 2011; Mainlay and Tan, 2012; Lawson et al., 2020). Poor women are the most vulnerable and most affected by climate change, especially in developing countries (Swai et al., 2012). Bangladesh, one of the developing countries from the global south, is at a high risk of frequent climatic disasters such as flooding, cyclone, riverbank erosion, sea-level rise, etc. Though natural disasters affect all population groups, some researchers have found gender-specific exposure and disaster effects. This vulnerability is more triggered by other social problems such as sexual integrity and poverty, mainly confronted by women and adolescent girls, making them further insecure and shocked (Azad et al., 2013). Therefore, women here are more susceptible than men to climate-related impacts because of their social condition, cultural norms, lack of access to and control over resources, and lack of participation in decision-making processes (Khan et al., 2010). Among other South Asian countries, the geographical context has made Bangladesh more vulnerable to seasonal flooding, causing tremendous loss of human life and property. An average of 844,000 million cubic meters of water runs across the country during the rainy season (May-October) through the three most important river systems- the Ganges, the Brahmaputra, and the Meghna. As a low-lying country where almost eighty percent of the landmass covers floodplain, it exposes to repeated floods (Dewan, 2015). The marginal and disadvantaged group of people, including the poor, physically challenged, and ethnic minorities, are the forefront victims of the aftereffect of any natural disasters, including floods. More precisely, among these groups of the marginal community, women, children, and adults' susceptibility are of the highest degree. However, individuals could play a significant role in responding to a changing climate and disaster situation (CCC, 2009).

For decades social scientists and environmental sociologists have researched gender dynamics in scientific understanding and the ecological problem. The results are a combination of robust designs as well as unresolved consequences. These consist of a multidisciplinary study exploring public opinion on climate change or global warming, a vital science-based environmental issue full of political controversy and moral concern (McCright, 2010). Most previous studies (ex. Pearse, 2017; Swai et al., 2012; McCright, 2010) concentrated on gender relations of climate change, exploring vulnerability and adaptation in different contexts, and knowledge and social action targeting both males and females. However, there is hardly ever any study (ex. Selm et al., 2019; Lawson et al., 2020) that focuses principally on women or women-headed households and their perspectives of basic understanding of climate change and knowledge of its adaptation and response options. Besides, less work is being done on a systematic public opinion analysis that explores the conceptual dimension of gender relations with climate change attitudes and beliefs. Conversely, researchers generally include gender as a statistical control in multivariate models and then only explain this variable's effectiveness in passing - often with little or no empirical discourse (McCright, 2010). A noticeable number of researches (ex. Huq et al., 1999; Alam et al., 2017; Rahaman et al., 2019; Rahaman and Rahman, 2020) have assessed the implications of climate change in different sectors in Bangladesh. In contrast, the study on climate change impacts on ultra-poor women and their risk perceptions is less explored. Instead, most studies 
consider multiple groups of vulnerable populations in their studies (ex. Haq and Ahmed, 2017). Thus, this study will examine the risk perceptions of these less explored population groups, particularly women.

Sirajganj district is historically known as one of the most vulnerable areas in Bangladesh that face frequent seasonal flooding and havoc visits. Sirajganj is inundated nearly each year, with the most drastic floods occurring in 1949, 1956, 1961, 1962, 1966, 1968, 1974, 1979, 1987, 1988, 1996, 1998, 2002, 2004, 2007, 2008, 2014, 2016, and 2019 (Ali et al., 2019). Khan et al. (2010) have shown that the intensity of extreme climatic events such as flooding, impact, and response depends on the socio-economic conditions amongst a vulnerable group of people, including the poor, ultra-poor, and wealthy class. Both the hard and soft adaptation knowledge is crucial to coping with the distractions caused by extreme disasters. A local community, affected by the unexpected conditions due to climate change, tries different alternatives and strategies to cope with it. Affected people adopt livelihood strategies using their indigenous knowledge and coping mechanisms. Among the strategies, diversification of livelihoods and cropping patterns, such as introducing floating gardening, poultry and duck rearing, cage aquaculture, building sea wave protection walls, pond or canal excavation, and dam construction, are remarkable, and mostly these are hard adaptation measures (Anik et al., 2012).

Women and women-headed households in rural areas like the Sirajganj district, in general, are more likely to experience more poverty than the urban areas and, at the same time, more vulnerable than men to various natural disasters, including flooding. Moreover, widowed women are supposed to be weaker in social safety and empowerment than those with a well-earning husband or rich and good-family-network. Women also have less socio-economic power compare to men. In village areas, men go to cities searching for jobs, leaving women in their home village. Women in the town often look after their families and work harder to feed their children or dependent. Thus, reasonably women are more likely than men to be experienced with local disasters in flood-prone areas. Therefore, climate change impacts affect vastly ultra-poor women in remote and rural flood-prone regions. The activities of women in the affected area are also noteworthy. Women are involved in cultivation, and post-harvest works along with men (NAPA, 2009). They are also taking part in tailoring, fishnet making, cattle farming, poultry, and handicrafts making. In rural communities, women overwhelmingly undertake the labor of collecting food, water, and energy resources for cooking that increase collection time. Women's activities contribute to their families' existence by ensuring food security (Nasreen, 2008; 2012). However, lack of access and ownership of land and wealth makes women vulnerable to economically challenged situations triggered by environmental stresses. Thus, knowledge and understanding of climate change and its impacts and response could be an essential tool for promoting soft adaptation strategies and improving their coping capacities in such rural floodprone areas. This knowledge will also help them in keeping their families safe during the disaster period. 
This study has been carried out to understand the perception and impact of climate change among ultra-poor vulnerable women and find out local adaptation options, particularly in the highly susceptible flood-prone areas like the Sirajganj district of Bangladesh. Along with other statistical analyses, Structural Equation Modeling (SEM) has been used to understand any links between climate change perceptions and other associated variables. Based on this study's background literature materials, this SEM will be a noble work as none of these studies addressed this issue in the Bangladeshi context. Therefore, this study will provide a proper guideline on using SEM for climate change studies in Bangladesh, particularly flood-prone areas.

\section{Methods}

\subsection{Study Area}

Chowhali Upazila under the Sirajganj district is one of the most vulnerable flood-affected areas in Bangladesh. This study was conducted in seven unions of the Upazila; most of the unions are flood affected. This Upazila lies between $24^{\circ} 01^{\prime} \mathrm{N}$ and $24^{\circ} 17^{\prime} \mathrm{N}$ latitudes and between $89^{\circ} 41^{\prime} \mathrm{E}$ and $89^{\circ} 59^{\prime} \mathrm{E}$ longitudes. The entire Upazila covers 21,039 hectares area (Figure 1). The Jamuna River passes through the Upazila that brings ample bank erosion, causing the displacement of many human settlements. Hassan et al., (2016) conducted a remote sensing study using three multi-date Landsat imageries. It estimated that about 1340-hectare areas had been eroded between 1989 and 2015 in different parts of the entire study area. This zone is mainly selected as the study area due to its high vulnerability to flood, river erosion, and climate change's adverse impacts. 


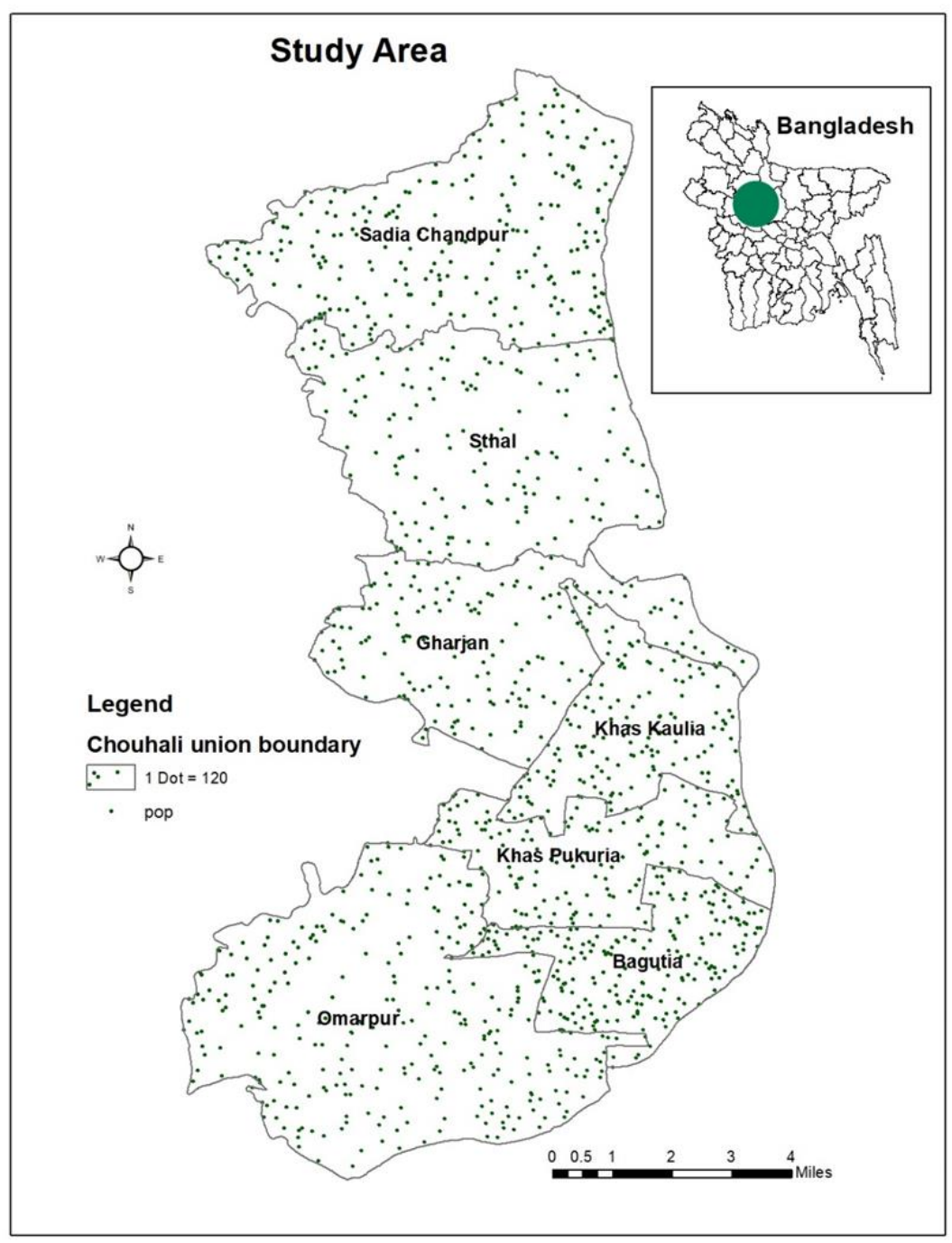

Future 1: Location map of the study area.

\subsection{Data Collection and Analysis}

In this research, both quantitative and qualitative approaches were applied to explore the perception of different vulnerabilities of vulnerable women due to climate change in the study area. In the quantitative approach, a mini-structured questionnaire with twenty key questions related to the study's primary objectives was used. The survey was collected responses from 200 climate-vulnerable ultra-poor women in 7 unions of the Upazila. The study undergoes a random sampling method to extract 200 respondents, following a 95\% confidence level with a $5 \%$ margin of error. The average sample size of each union was 30 climate-vulnerable women with having similar socio-economic status and criteria. These specific criteria were: (1) suffer daily food insecurity, (2) no land or less than 0.15 acres, (3) deplorable housing condition, (4) womenheaded household, and (5) no active male income earner. In the qualitative data collection method, ten Key Informant Interviews (KIIs) were also conducted from school teachers, Union 
Parishad members, Union Parishad chairpersons, and elite persons who know the environment, climate change, and overall socio-economic status of the study area. The survey's primary focus was to define which climate change variables are impacting respondent's livelihood and socioeconomic parameters and how to mitigate and adapt to climate change impacts locally. The data collection took place in the study area from February- March 2019 with the help of 10 data collectors, who were appointed locally due to familiarity with the study area. Before collecting responses from respondents, two-day training was conducted on the whole questionnaire to minimize possible non-sampling errors. After receiving and cleaning all the feedback, SPSS version-23 was used to analyze the collected data. Moreover, some significant descriptive statistics such as mean value, total number, range, regression, percentage, and standard deviation were produced to analyze the surveyed data.

Structural Equation Modeling (SEM) is a widely used statistical modeling tool in social science research where a combination of path analysis, factor analysis, and multiple regressions is prevalent to delve into the different latent and apparent relationship of variables (Hox et al., 1998). To perform an SEM in the study, one dependent variable- climate change is true; and three independent variables- adequate knowledge on climate change; the reason for climate change; is it a long-term problem; and the role of the local government was used following a path model using SPSS software. This equation is an excellent way to conduct and show multiple regression models that permit dichotomous variables (Boon, 2016).

\section{Results}

\subsection{Socio-economic Profiles}

In this study, only female respondents were counted for the survey. The total respondents were aged between 20 and 60 years old. About $47 \%$ of the respondent's age was between 20 and 35 years. The interviewee's second majority age group was 35 to 45 years old, $41 \%$ of the total respondents.

Women can be the best way to emphasize adaptation to climate change impacts (UNICEF, 2016). In this study, the educational status of the respondents portrays a poor picture. Only $25 \%$ of the respondents completed primary education. Most interviewees (43.7\%) did not finish their primary school, while just $18.7 \%$ of the interviewees could only sign their names. The highest literacy rate was among $12.5 \%$ who completed secondary education. Thus, about $67 \%$ of women were most vulnerable due to a lack of primary education. Boon (2016) argued that the perception of climate change can increase with proper education and training.

Most of the respondents were housewives accounting for $49 \%$. The next dominant group had either small poultry or did cattle raised at the household level. Only $8 \%$ of the respondents were engaged in tailoring at the community level. $40 \%$ of the interviewees were landless, and $7 \%$ of 
respondents live in khash land ${ }^{1}$. About $34 \%$ of respondents had marginal households, and $19 \%$ had small families.

\subsection{Perceptions of Climate Change}

The study shows that only $37 \%$ of the respondents were concerned with climate change's general concept (Figure 2). The rest of the 63\% never heard about climate change. When the respondents familiar with the topic asked about the source of the knowledge of climate change, a significant number $(55 \%)$ replied NGO as a source, followed by T.V. (26\%) and radio (19\%). This study reveals that direct education, training, or communication positively impact educating vulnerable poor women on climate change-related issues. In addition to this finding, most of the respondents did not have proper scientific explanations and climate change results.

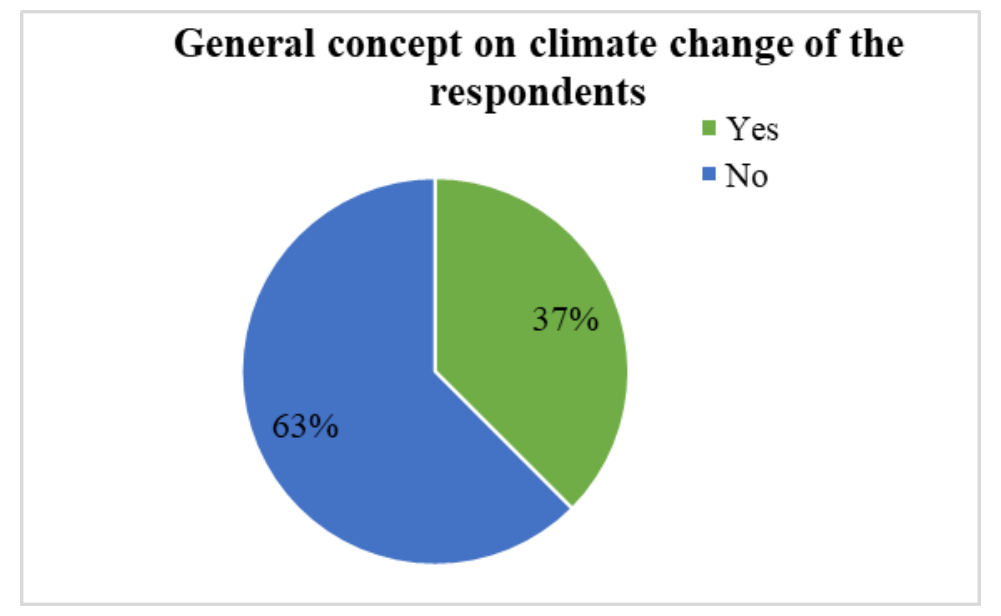

Figure 2: Respondent's general concept about climate change.

\subsection{Major Changes in Climate}

Figure 3 demonstrates the main climatic changes over the last 30 years noticed by the respondents. All the respondents observed irregular and less rainfall (Figure 3) in the study area, while $93 \%$ said rain was not in time. The overall climate change scenario in the study area is exposed to less rainfall and increasing temperature trend during the past 30 years. $93.7 \%$ of the respondents replied about a more extended summer period, while $87.5 \%$ talked about a shorter winter period. $93.7 \%$ of the interviewees found that winter does not appear timely over the last 30 years, whereas $56 \%$ observed severe cold wave conditions during winter. $37.5 \%$ of the respondents experienced severe heat waves during the summer. Half of the interviewees witnessed the increasing natural disasters during the last 30 years.

\footnotetext{
${ }^{1}$ Government owned fallow land.
} 


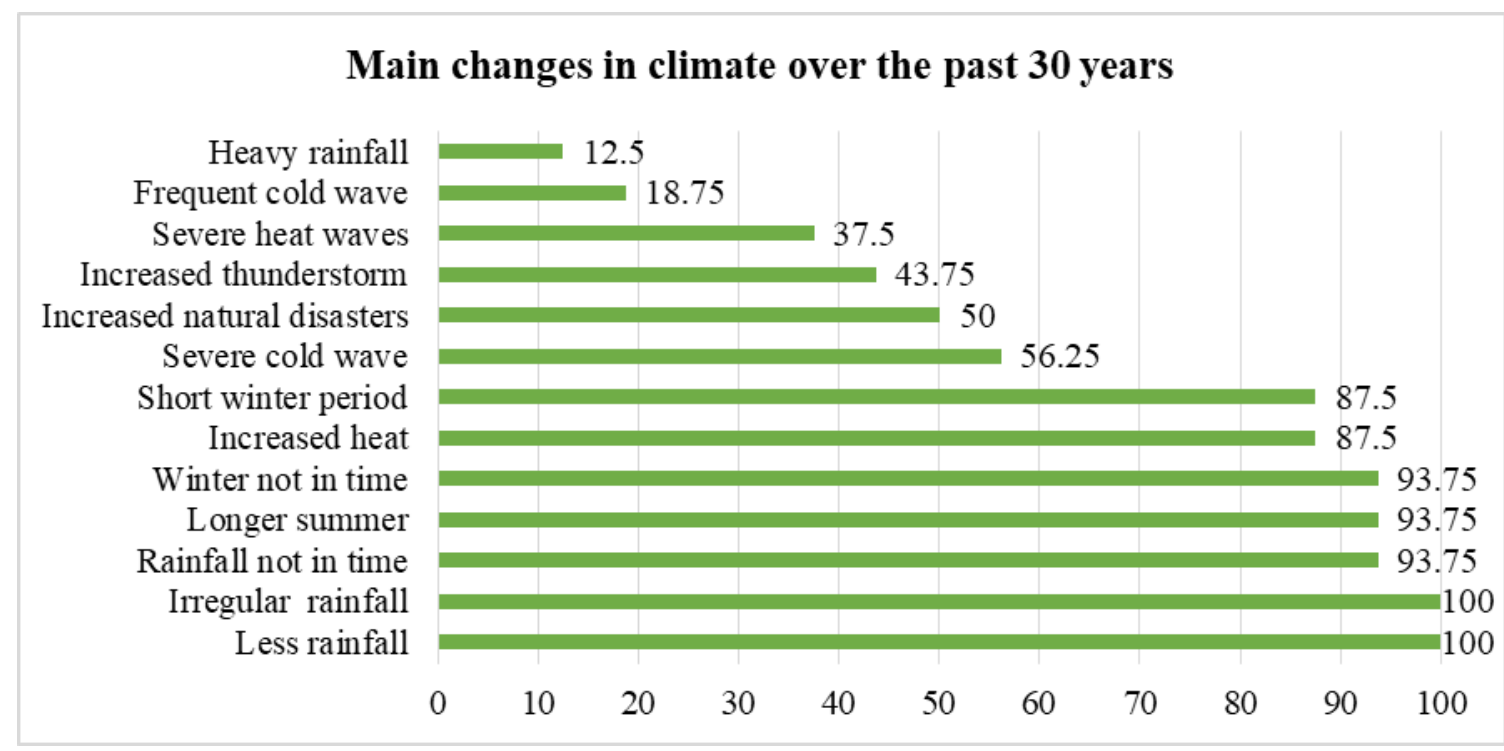

Figure 3: Main climatic changes observed by the respondents.

\subsection{Major Changes in the Ecosystem and Environment}

The impacts of climate variability and change in the study are severe, shown in Figure 3. Based on this figure, the development of the overall ecosystem and environmental sustainability is in danger that may affect the socio-economic and agriculture areas also. All of the respondents perceived drought conditions during the dry season. About $93.8 \%$ of the interviewees witnessed river erosion and mentioned lowering the groundwater level (Figure 4). Half of the respondents realized the loss of natural resources over the last 30 years. Many interviewees $(87.5 \%)$ claimed that there was less abundance of flora and fauna, indicating the loss of species. Approximately $81 \%$ of respondents witnessed less water in the river and wetlands. About $43.75 \%$ of respondents mentioned floods as significant adverse impacts. Heavy rainfall is another negative consequence during the last 30 years, referred by $25 \%$ of respondents. $31 \%$ of the interviewees indicated the increasing trend of water-borne diseases as major public health issues in the study area. 


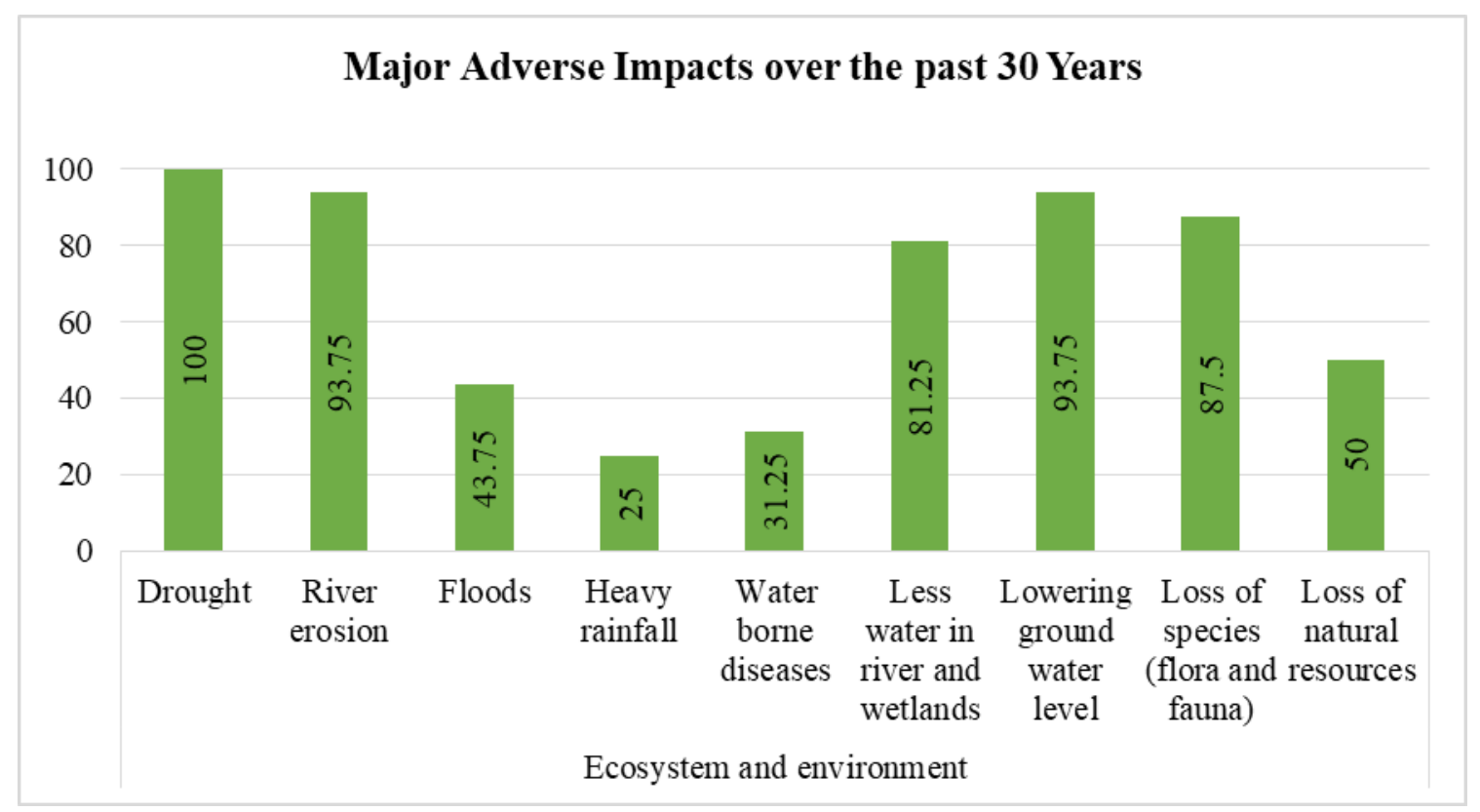

Figure 4: Major adverse impacts on the ecosystem and environment.

\subsection{Major Changes in Human Well-Being}

Climate change and its consequences not only have effects on the environment but also human well-being. $81 \%$ of the respondents suffered internal migration due to poverty and family demands (Figure 5). The same number of respondents experienced sleepless nights due to extreme heat conditions, which resulted in less body stamina and affected the laborious job. $62.5 \%$ of the respondents answered health-related problems like diarrhea, fever, and other air and water-borne diseases in the study area. About $43.75 \%$ of the respondents got lower work hours due to adverse impacts of climate change, and a similar percentage mentioned mental stress in their daily life. As a result, less income from fewer working hours was also identified by some respondents $(37.5 \%)$. Therefore, this study's results reveal that the poverty situation can be a dangerous and increasing trend because about $19 \%$ of the interviewees believed this is happening in their area. 


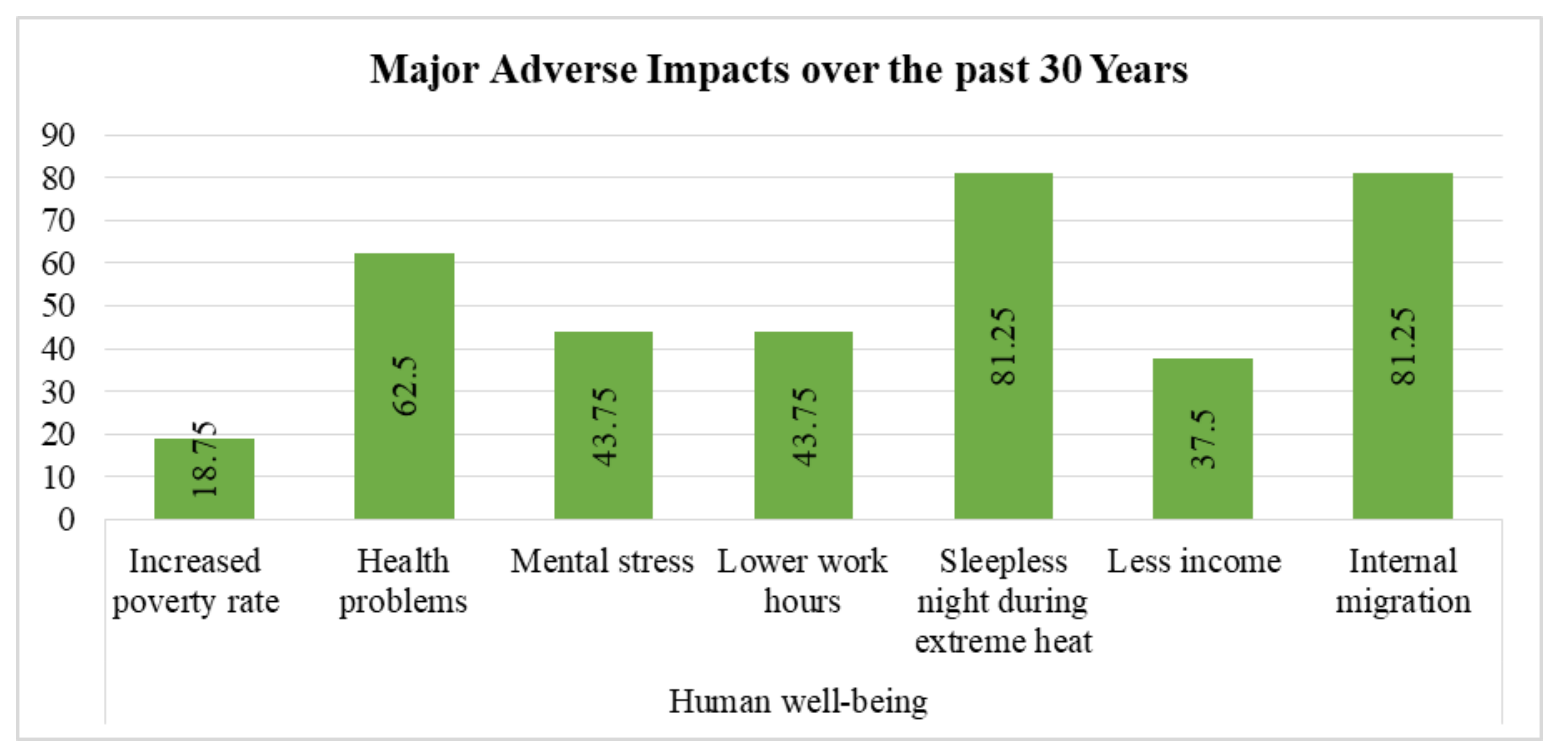

Figure 5: Major adverse impacts on human well-being.

Figure 6 represents the percentage of a different group of people that are the most vulnerable in Bangladesh due to climate change effects. Among the vulnerable groups, children are the most affected, $87 \%$ of the total people affected. Adolescent girls and women are also vastly affected. Illness is also on the top list.

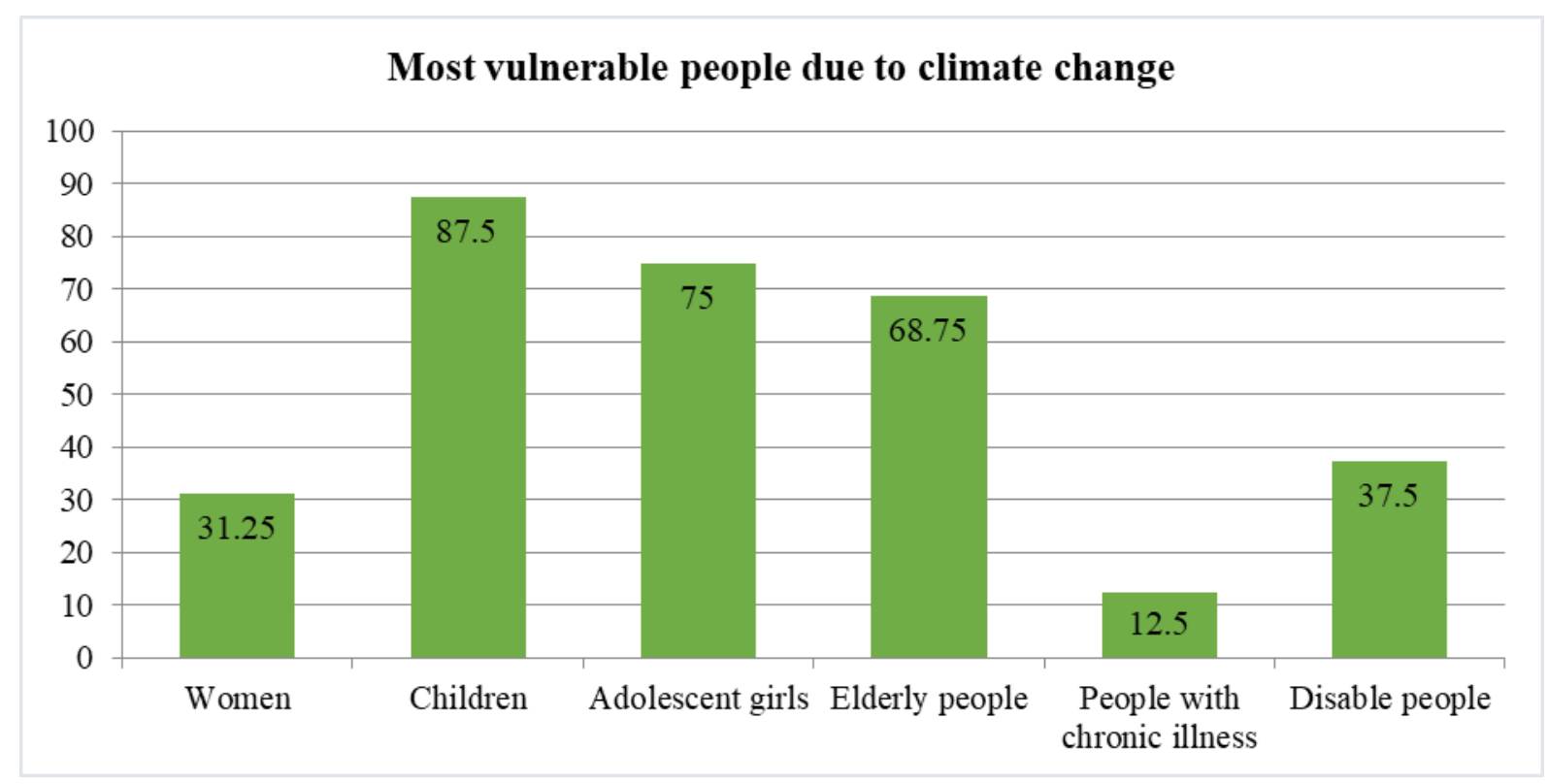

Figure 6: Different climate change vulnerable groups.

\subsection{Major Changes in Agriculture}

As an agricultural country, the effects of climate change on agriculture are one of the most significant concerns. All the respondents agreed to the point that climate change has an impact 
on the loss of soil fertility and increased crop production cost (Figure 7). All interviewees also opined that plant or agriculture lands go underwater during flooding and sometimes covered with sand. The next significant adverse impacts are crop failure, which was opined by $87.5 \%$ of the respondents. About $75 \%$ of the respondents also indicated a loss of crop yields as an initial impact. About $37.5 \%$ of respondents pointed out irrigation problems, and $18.7 \%$ noticed the unknown plant diseases. One-fourth of the interviewees mentioned that the food crisis exists in the study area.

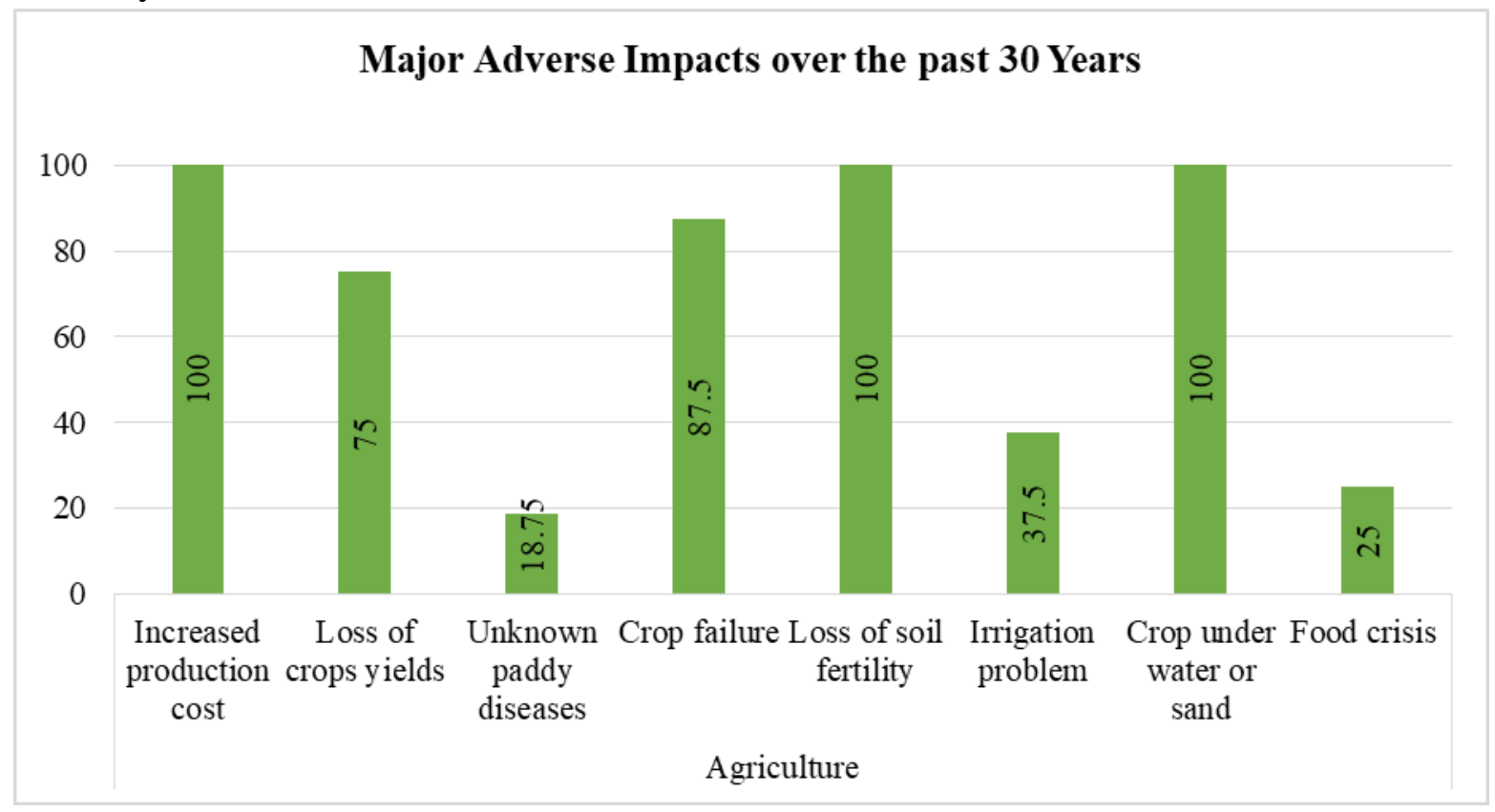

Figure 7: Major adverse impacts on agriculture.

\subsection{Local Adaptation to Climate Change}

Figure 8 shows the current adaptation options for climatic impacts. Plinth raising (100\%), livestock rearing $(100 \%)$, homestead gardening $(81.25 \%)$, and seasonal migration $(81.25 \%)$ are popular adaptation options in the study area. Other options include the change of livelihood, taking a loan, using indigenous knowledge, crop diversification, selling household assets, mortgaging land, a loan from NGO, tree plantation, and seasonal fishing. People affected by the climate change consequences have tried many ways of adapting by spending their own money. 


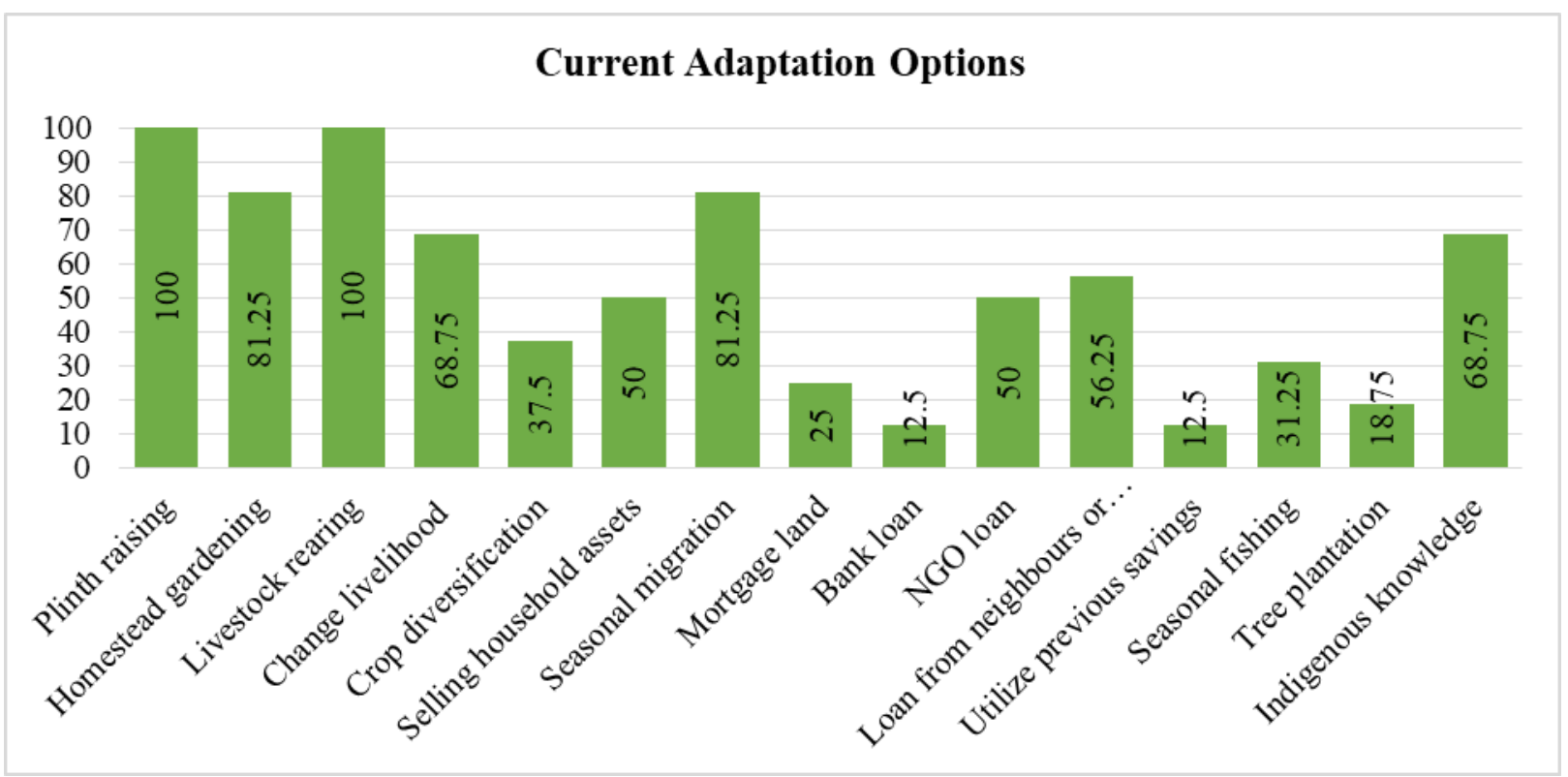

Figure 8: Present climate change adaptation options.

\subsection{Investment for Local Adaptations}

To apply local adaptation options to climate change, about $32 \%$ of the respondents spent 3500 BDT (\$45) or more, $18 \%$ spent 3000-3500 BDT (\$38-45), 27\% spent 2500-3000 BDT (\$32-38), $16 \%$ spent 2000 to 2500 BDT (\$25-32) and 7\% of the affected people spent 1500 to 2000 BDT (\$20-32) once in the study area. These costs include recovery actions after any climatic strike like the flood, riverbank erosion, and drought condition. This expense also includes migration to other places due to the impact of climate change.

The results of Structural Equation Modeling (SEM), which included one dependent and three independent variables, reveal that about $49 \%$ of the variance (R2) evidencing the existence of climate change in the study area. It means that a sizable portion of possible influences impacts climate change by some significant variables used in this model. Figure 9 shows climate change will be a long-term problem, which showed a sharp predictor in this model considering standardized regression weight $\beta=0.56$. Climate change knowledge was a very small predictor, standardized regression weight of which was $\beta=-.52$, in this model. It means, despite inadequate expertise on climate change of the respondent's, climate change is happening and becoming the worst factor delaying cultural, economic, and environmental development in the study area. 


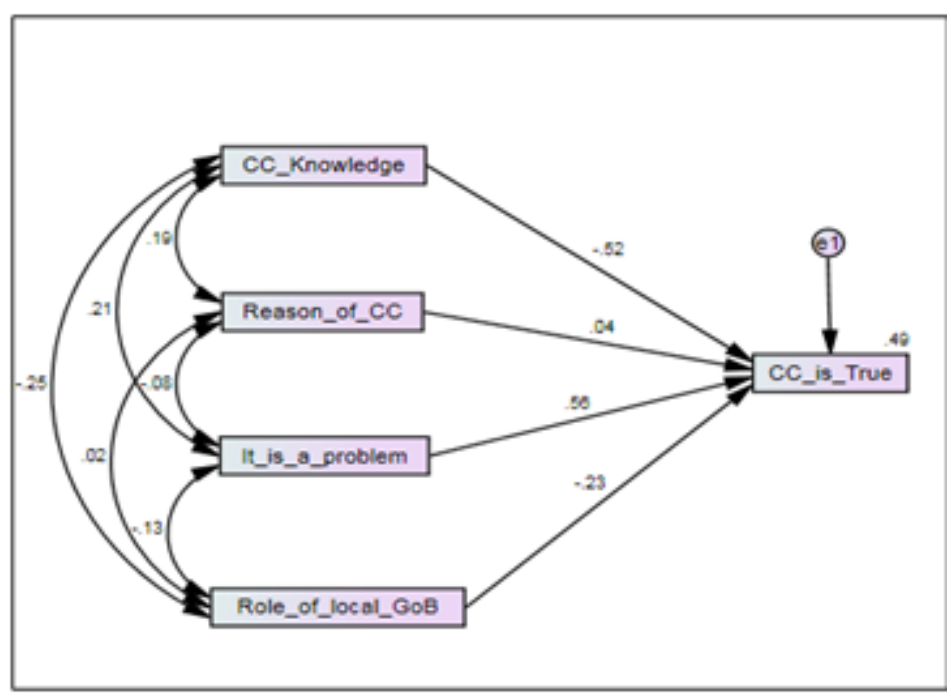

Figure 9: The SEM model structure and its pathways

Table 1: Model outputs derived from the SEM.

\begin{tabular}{|c|c|c|c|c|c|c|}
\hline $\begin{array}{l}\text { Dependent } \\
\text { variable }\end{array}$ & & Independent variables & Estimation & S.E. & C.R. & $\mathrm{P}^{*}$ \\
\hline CC_is_True & $\begin{array}{ll}<-- \\
\end{array}$ & CC_Knowledge & -.651 & .178 & -3.664 & $* * *$ \\
\hline CC_is_True & $<---$ & Reasons_of_CC & .058 & .216 & .267 & .789 \\
\hline CC_is_True & $<---$ & It_is_a_problem & .523 & .128 & 4.098 & $* * *$ \\
\hline CC_is_True & $<---$ & Role_of_local_GoB & -.349 & .209 & -1.675 & .094 \\
\hline
\end{tabular}

*Sig value $P<0.001$

Table 1 reveals that the respondents' climate change knowledge and problems of climate change are statistically significant at $\mathrm{P}<0.001$. It means that the respondents realized climate change is true, which will be impacted long-term on their socio-economic and cultural lives. Moreover, they believed that it is happening due to not only anthropogenic but also other natural reasons. In addition to this finding, the role of local government and climate change causes did not have any significant influences on climate change. Consequently, this statistical result shows that climate change is an emerging situation that can affect the local livelihoods, agriculture, economy, food security, and women empowerment. The local government's role is instrumental in identifying existing climate change problems and developing local adaptation action plans in their Annual Development Program (ADP). Different frontline workers of the government, along with NGOs, schools, youth, and civil society movements, can play a significant role in enhancing the knowledge on climate change for the local community.

\section{Discussion}


The study shows that the traditional understanding of climate change is concerned only by a small number, whereas the majority of women respondents do not know the word. The primary sources of knowledge gathered on climate change were the local stakeholders, including government, NGOs, and the conventional media such as radio and TV. The area has experienced notable shifts in different climate and weather conditions, including erratic and excessive rainfall, shorter winter and longer summer seasons, summer heat stress, cold winter, and monsoon floods, and a steady trend in different natural disasters in the recent decades. Such changes in climate and environment have increased the severity and frequency of the natural disasters such as floods, erosion, and drought, and so on. Almost all of the ultra-poor participants experienced river erosion by the Jamuna River. It forced several hundred people to move away from their land of origin. Approximately 80,690-hectare lands had eroded along the 240 kilometers Jamuna River in between 1973 and 2009 (Shaw et al., 2013). It destroyed many properties and made the respondents suffer economically. These events also contributed to increased waterborne diseases and depletion of natural resources and eventually impacted local population livelihoods, including women at risk. Women choose the alternative forms of living, for example, livestock raising, poultry, home gardening, and shift in livelihoods. Sometimes they move seasonally to big towns in search of work and take a loan or even sell the household property to cope with the adverse situation. Cannon (2002); Sultana (2010); Khalil et al. (2019) indicated the same pattern of male members relocating from local areas to the closest cities to seek jobs. Abedin et al. (2013) spoke about multi-strategies such as child-education, storage of essential items, borrowing money, selling and mortgaging properties, relocation and finding alternative jobs, and so on. Khalil et al. (2019) also found that women work as day laborers, make crafts, and catch fish and crabs and other non-traditional jobs, to provide their families with livelihoods.

This study is the advanced research of climate change to understand the perceptions and impacts in this particular flood-prone area and shows a low perception strategy among the target group of affected people. Few climate-vulnerable ultra-poor women were concerned with climate change issues. Both government and NGO can play a significant role to bring awareness to them. To reduce the impacts of climate change, the National Plan for Disaster Management (2008-2015) formed a Disaster Management Committee for five administrative levels (District, upazila, union parishads, municipalities, and City Corporation) to mitigate the climate change impacts. Based on the Bangladesh Climate Change Strategy and Action Plan (BCCSAP-2009), the government set six key priorities/pillars to guide the integration of climate change issues into the main development frameworks to make a holistic effort at different ministerial levels. Already the National Adaptation Programs of Action (NAPA) have been published and started implementation with its primary goal of reducing the effects of climate change and promotes sustainable development at central to community levels (NAPA, 2009). Based on different substantial pieces of evidence and studies, NGOs are the principal source of transferring knowledge about climate change to grass-roots people. They can add-on the climate change as an essential cross-cutting issue in their all of the development projects to mitigate the impacts of 
climate change. Many NGOs in Bangladesh are working on climate change adaptation issues focusing on life-skills and income generation activities for improving household and community development (Lönnqvist et al., 2010).

Electronic media can play a vital role to provide the information about climate change. Media can promote the climate change policies through proper research, live documentary, roundtable discussion, special supplementary, and features (Haque et al., 2010). Therefore, it is essential to make and provide the sufficient information on the climate change issues and adaptation processes for community people through electronic media. Mujaffor (2011) argued that growing awareness and dissemination on climate change issues through different media channels can play a crucial role in improving sustainable development at the community level.

The findings of Structural Equation Modeling (SEM) are significant in the study because, local government institutions and officials do not have adequate management and coordination skills to tackle different impacts of climate change. Moreover, various government initiatives like Sustainable Development Goals (SDGs), National Adaptation Plan (NAP), National Biodiversity Strategy and Action Plan, National Adaptation Programs of Action, National Action Programme for Combating Desertification, Bangladesh Capacity Development Action Plan, National Sustainable Development Strategy, National Climate Change Strategy, and Action plan, National Sustainable Development Strategy should have vital roles in enhancing climate change knowledge and adaptation to rural and urban communities. The following recommendations can be useful adaptation measures depending on the outcomes of this study:

- Introducing the human security framework in the policymaking to adapt to climate change.

- In national climate change policies, the programs should essentially include gender perspective adaptation policies..

- Ensuring women's participation in climate change dialogue and decision making at local, regional, and national levels.

- National Adaptation Programme of Action (NAPA) should be revised and include a gender perspective, especially for ultra-poor women.

- Encouraging more research on the gender-specific vulnerabilities of climate change

- Policies can be categorized based on the climate hazard types and affected areas.

- Policies and legislation also should focus on the sustainable development goals

- Initiate adaptation funds for the most affected areas and most vulnerable people to climate change.

\section{Conclusion}

This study explores the different perceptions of climate change and its adaptation options from ultra-poor women in the study area using a set of quantitative and a few KIIs data. Along with some descriptive statistical analyses, this study conducted a sophisticated Structural Equation 
Modeling (SEM) to delve into different internal and apparent relationships between some fundamental variables standard for the climate change studies. This study reveals that the perception of climate change at participants' level is relatively low (63\%), but they have observed the significant differences in climatic parameters over the past 30 years. To tackle these changes and impacts, they adopt some local indigenous methods to improve the existing ecosystem and environment, agriculture, human well-being, and overall socio-economic developments. As a result, they had to invest in implementing these adaptation processes ranging from \$20-45 at the household level. From the SEM results, climate change is real and happening in this study area. Therefore, the roles of local government, along with other development actors, can incorporate the existing policies into any regional planning and developments in the study area. The main limitation of this study was the low sample size and not using other secondary information.

Further research on this similar issue may have a robust sample size with mixed-method data collection and analysis. However, this study can be used as technical guidance for analyzing the similar ecosystem data in Bangladesh and other areas. Local government, NGOs, and other development actors may use these findings for preparing any development initiatives in the study area related to the climate change and environmental studies.

\section{References}

Abedin, M. A., Habiba, U., and Shaw, R. (2013). Gender and Climate Change: Impacts and Coping Mechanisms of Women and Special Vulnerable Groups. In Climate Change Adaptation Actions in Bangladesh, pp. 165-184, Springer, Tokyo, Japan.

Alam, G. M., Alam, K., and Mushtaq, S. (2017). Climate change perceptions and local adaptation strategies of hazard-prone rural households in Bangladesh. Climate Risk Management, 17, 52-63.

Ali, M. H., Bhattacharya, B., Islam, A. K. M. S., Islam, G. M. T., Hossain, M. S., and Khan, A. S. (2019). Challenges for flood risk management in flood-prone Sirajganj region of Bangladesh. Journal of Flood Risk Management, 12(1), e12450.

Anik, S. I., and Khan, M. A. S. A. (2012). Climate change adaptation through local knowledge in the north eastern region of Bangladesh. Mitigation and Adaptation Strategies for Global Change, 17(8), 879-896.

Arora-Jonsson, S. (2011). Virtue and vulnerability: Discourses on women, gender and climate change. Global Environmental Change, 21(2), 744-751. Australian Towns. Reg. Environ. Change. DOI 10.1007/s10113-014-0744-3

Azad, A. K., Hossain, K. M., and Nasreen, M. (2013). Flood-induced vulnerabilities and problems encountered by women in northern Bangladesh. International Journal of Disaster Risk Science, 4(4), 190-199. 
Baptiste, A. K., and Kinlocke, R. (2016). We are not all the same!: Comparative climate change vulnerabilities among fishers in Old Harbour Bay, Jamaica. Geoforum, 73, 47-59.

Boon, H. J. (2016). Perceptions of climate change risk in four disaster-impacted rural Australian towns. Regional Environmental Change, 16(1), 137-149.

Cannon, T. (2002). Gender and climate hazards in Bangladesh. Gender and Development, 10(2), 45-50.

Carr, E. R., and Thompson, M. C. (2014). Gender and climate change adaptation in agrarian settings: Current thinking, new directions, and research frontiers. Geography Compass, 8(3), 182-197.

CCC (Climate Change Cell). (2009). Climate change, gender and vulnerable groups in Bangladesh. Climate Change Cell (CCC), Ministry of Environment and Forests, Government of the People's Republic of Bangladesh, Dhaka.

Dewan, T. H. (2015). Societal impacts and vulnerability to floods in Bangladesh and Nepal. Weather and Climate Extremes, 7, 36-42.

Field, C.B., V.R. Barros, K.J. Mach, M.D. Mastrandrea, M. van Aalst, W.N. Adger, D.J. Arent, J. Barnett, R. Betts,T.E. Bilir, J. Birkmann, J. Carmin, D.D. Chadee, A.J. Challinor, M. Chatterjee, W. Cramer, D.J. Davidson, Y.O. Estrada,J.-P. Gattuso, Y. Hijioka, O. HoeghGuldberg, H.Q. Huang, G.E. Insarov, R.N. Jones, R.S. Kovats, P. Romero-Lankao,J.N. Larsen, I.J. Losada, J.A. Marengo, R.F. McLean, L.O. Mearns, R. Mechler, J.F. Morton, I. Niang, T. Oki, J.M. Olwoch,M. Opondo, E.S. Poloczanska, H.-O. Pörtner, M.H. Redsteer, A. Reisinger, A. Revi, D.N. Schmidt, M.R. Shaw,W. Solecki, D.A. Stone, J.M.R. Stone, K.M. Strzepek, A.G. Suarez, P. Tschakert, R. Valentini, S. Vicuña, A. Villamizar,K.E. Vincent, R. Warren, L.L. White, T.J. Wilbanks, P.P. Wong, and G.W. Yohe, 2014: Technical summary. In: ClimateChange 2014: Impacts, Adaptation, and Vulnerability. Part A: Global and Sectoral Aspects. Contribution of WorkingGroup II to the Fifth Assessment Report of the Intergovernmental Panel on Climate Change [Field, C.B., V.R. Barros,D.J. Dokken, K.J. Mach, M.D. Mastrandrea, T.E. Bilir, M. Chatterjee, K.L. Ebi, Y.O. Estrada, R.C. Genova, B. Girma,E.S. Kissel, A.N. Levy, S. MacCracken, P.R. Mastrandrea, and L.L. White (eds.)]. Cambridge University Press,Cambridge, United Kingdom and New York, NY, USA, pp. 35-94.

Grothmann, T., and Patt, A. (2005). Adaptive capacity and human cognition: the process of individual adaptation to climate change. Global Environmental Change, 15(3), 199-213.

Haq, S. M. A., and Ahmed, K. J. (2017). Does the perception of climate change vary with the socio-demographic dimensions? A study on vulnerable populations in Bangladesh. Natural Hazards, 85(3), 1759-1785.

Haque, M. A., Yamamoto, S., and Sauerborn, R. (2010). Print Media and Climate Change in Bangladesh: The Missing Health Issue. In Proc. of International Conference on Environmental Aspects of Bangladesh (ICEAB10), Japan.

Hassan, M. and Mahmud-ul-islam, S. (2016). Quantification of River Bank Erosion and Bar Deposition in Chowhali Upazila, Sirajganj District of Bangladesh: A Remote Sensing 
Study. Journal of Geoscience and Environment Protection, 4, 50-57. doi: 10.4236/gep.2016.41006.

Hine, D. W., Reser, J. P., Phillips, W. J., Cooksey, R., Marks, A. D., Nunn, P., ... and Glendon, A. I. (2013). Identifying climate change interpretive communities in a large Australian sample. Journal of Environmental Psychology, 36, 229-239.

Hox, J. J., and Bechger, T. M. (1998). An introduction to structural equation modeling.

Huq, S., Karim, Z., and Asaduzzaman, M. (1999). Vulnerability and adaptation to climate change for Bangladesh. F. E. Mahtab (Ed.). The Netherlands: Kluwer Academic Publishers.

Kahan, D. M. (2008). Cultural cognition as a conception of the cultural theory of risk. Handbook of Risk Theory, S. Roeser, ed., Forthcoming, 08-20.

Kahan, D. M., and Braman, D. (2003). More statistics, less persuasion: A cultural theory of gunrisk perceptions. University of Pennsylvania Law Review, 151(4), 1291-1327.

Kahan, D. M., Jenkins-Smith, H., and Braman, D. (2011). Cultural cognition of scientific consensus. Journal of Risk Research, 14(2), 147-174.

Khalil, M. B., Jacobs, B. C., McKenna, K., and Kuruppu, N. (2020). Female contribution to grassroots innovation for climate change adaptation in Bangladesh. Climate and Development, 12(7), 664-676.

Khan, I. A., Ali, Z., Asaduzzaman, M., and Rashid Bhuyan, M. H. (2010). The social dimensions of adaptation to climate change in Bangladesh, No. 58899, pp. 1-98, The World Bank.

Lacroix, K., and Gifford, R. (2018). Psychological barriers to energy conservation behavior: the role of worldviews and climate change risk perception. Environment and Behavior, 50(7), 749-780.

Lawson, E. T., Alare, R. S., Salifu, A. R. Z., and Thompson-Hall, M. (2020). Dealing with climate change in semi-arid Ghana: Understanding intersectional perceptions and adaptation strategies of women farmers. GeoJournal, 85(2), 439-452.

Lönnqvist, L., Huda, N., Kabir, N., Kaisari, R. Z., Khandker, M., and Chandra, S. S. (2010). Shortcut to the frontline: supporting local NGOs on climate change in Bangladesh. Occasional Papers Series, (50).

Mainlay, J., and Tan, S. F. (2012). Mainstreaming gender and climate change in Nepal. International Institute for Environment and Development, London, UK.

McCright, A. M. (2010). The effects of gender on climate change knowledge and concern in the American public. Population and Environment, 32(1), 66-87.

Mujaffor, S.A. (2011). Climate Change in Bangladesh: Role of Mass Media. Asia-Pacific Forum on Mass Media and Education for International Understanding, Sydney, Australia.

NAPA. (2009). National Adaptation Programme of action. Ministry of Environment and Forests, Government of the People's Republic of Bangladesh, Dhaka.

Nasreen, M. (2008, August). Impact of climate change on food security in Bangladesh: gender and disaster perspectives. In International Symposium on Climate Change and Food Security in South Asia', Dhaka, Bangladesh, pp. 25-30. 
Nasreen, M. (2012). Women and Girls Vulnerable or Resilient? Institute of Disaster Management and Vulnerability Studies, University of Dhaka, Dhaka-1000, Bangladesh.

Pearse, R. (2017). Gender and climate change. WIREs Clim Change, 8: e451. https://doi.org/10.1002/wcc.451

Rahaman, M. A., and Rahman, M. M. (2020). Climate Justice and Food Security: Experience from Climate Finance in Bangladesh. Environmental Policy: An Economic Perspective, 249-268.

Rahaman, M. A., Rahman, M. M., and Rahman, S. H. (2019). Pathways of Climate-Resilient Health Systems in Bangladesh. In Confronting Climate Change in Bangladesh (pp. 119143). Springer, Cham, Germany.

Rosa, E. A. (2003). The logical structure of the social amplification of risk framework (SARF): Metatheoretical foundations and policy implications. The social Amplification of Risk, 47, 47-49.

Selm, K. R., Peterson, M. N., Hess, G. R., Beck, S. M., and McHale, M. R. (2019). Educational attainment predicts negative perceptions women have of their own climate change knowledge. PloS One, 14(1), e0210149.

Shaw, R., Mallick, F., and Islam, A. (Eds.). (2013). Climate change adaptation actions in Bangladesh. New York: Springer, USA.

Sjöberg, L. (2000). The methodology of risk perception research. Quality and Quantity, 34(4), 407-418.

Sultana, F. (2010). Living in hazardous waterscapes: Gendered vulnerabilities and experiences of floods and disasters. Environmental Hazards, 9(1), 43-53.

Swai, O. W., Mbwambo, J. S., and Magayane, F. T. (2012). Gender and perception on climate change in Bahi and Kondoa Districts, Dodoma Region, Tanzania. Journal of African Studies and Development, 4(9), 218.

UNICEF. (2016). Climate change and environmental education. Available on http://www.unicef.org/education/bege_61668.html [Accessed on June 07, 2019]

van der Linden, S. (2017). Determinants and measurement of climate change risk perception, worry, and concern. The Oxford Encyclopedia of Climate Change Communication. Oxford University Press, Oxford, UK.

Woods, B. A., Nielsen, H. Ø., Pedersen, A. B., and Kristofersson, D. (2017). Farmers' perceptions of climate change and their likely responses in Danish agriculture. Land use policy, 65, 109-120. 